\title{
HUBUNGAN ANTARA HIPERTENSI DENGAN PENURUNAN FUNGSI KOGNITIF PADA LANSIA
}

\author{
Anisa Wahyuniarti ${ }^{1}$, Moch Bahrudin ${ }^{2}$, Fathiyah Safithri ${ }^{3}$ \\ Fakultas Kedokteran Universitas Muhammadiyah Malang, J1. Bendungan Sutami 188 A Sumbersari malang, \\ Lowokwaru, Kota Malang, 65145, Indonesia, (0341) 582060
}

\begin{abstract}
ABSTRAK
Hubungan Antara Hipertensi Dengan Penurunan Fungsi Kognitif Pada Lansia. Latar Belakang: Hipertensi merupakan salah satu faktor terjadinya penurunan fungs kognitif. Pada orang lanjut usia terjadi penurunan kapasitas fungsional otak yang akan menimbulkan berbagai gangguan neuropsikologis salah satunya yaitu penurunan fungsi kognitif. Mini Mental State Examination (MMSE) merupakan salah satu cara untuk mendeteksi penurunan fungsi kognitif. Tujuan: Mengetahui Hubungan Antara Hipertensi dengan Penurunan Fungsi Kognitif Pada Lansia. Metode: Analitik observasional dengan pendekatan cross sectional. Besar sampel 63sampel. Dilakukan uji hipotesis Chi-Square untuk menentukan hubungan antar variable,dan dikatakan signifikan bila nilai $\mathrm{P}<0,05$ Hasil dan Diskusi: Didapatkan penurunan fungsi kognitif pada lakilaki sebanyak $22 \%$ sedangkan perempuan $54 \%$, pada umur 60-69 tahun sebanyak 42\%, umur 70-74 tahun sebanyak 38\% dan pada hipertensi Staduim I sebanyak $20 \%$, hipertensi stadium II sebanyak 38\% sedangkan pada penderita yang tidak hipertensi sebanyak 5\%, pada uji Chi Square didapatkan x2 =0,015 dan p < 0,05 Kesimpulan: Ada hubungan antara hipertensi dengan penurunan fungsi kognitif.
\end{abstract}

Kata Kunci: hipertensi, lansia, penurunan fungsi kognitif.

\begin{abstract}
The Relationship Between Hypertension and Decreased of Cognitive Function in Elderly People Background: Hypertension is one of the factors that decreased cognitive function. The elderly people has decreased brain functional capacity that would lead to neuropsychological disorders which is a decrease in cognitive function. Mini Mental State Examination (MMSE) is the test used to detect the decrease of functional capacity. Objective : To determine the Relationship Between Hypertension and Decreased of Cognitive Function in Elderly People Method: Observasional analytic with cross sectional method. The samples were 63 samples. The correlation within the variables were tested by Chi-Square hypothesis test and significant if $P<0,05$. Result and Discussion: Found a decrease in cognitive function in men by 22\% while 54\% female, age 60-69 years by 42\%, age 70-74 years were 38\% and the Staduim I bypertension by 20\%, stage II hypertension were 38\%, while hypertension in patients who are not as much as 5\%, the Chi Square test found $\times 2=0.015$ and $p$ $<0.05$ Conclusion: There is a relationship between bypertension and decreased of cognitive function in elderly people.
\end{abstract}

Key Words: bypertension, elderly people, decrease in cogntive function.

\section{PENDAHULUAN}

Gangguan kognitif adalah gangguan yang berkaitan dengan peningkatan usia. Gangguan ini menyebabkan penurunan fungsi otak yang berhubungan dengan kemampuan atensi, konsentrasi, kalkulasi, mengambil keputusan, reasoning, berpikir abstrak (Shiang Wu, 2011; Wiyoto, 2002). Salah satu gangguan kognitif yang menjadi masalah besar danserius yang dihadapi oleh negara-negara maju dan mulai muncul di negara-negara berkembang termasuk di Indonesia adalah dementia (Rohmah et al, 2006). Pada orang lanjut usia terdapat kecenderungan menurunnya kapasitas fungsional baik pada tingkat seluler maupun pada tingkat organ sejalan dengan terjadinya proses menua (Kaplan et al, 2010). Proses penuaan yang disertai proses degenerasi pada seluruh organ tubuh termasuk otak, akan menimbulkan berbagai gangguan neuropsikologis, dan masalah yang paling besar adalah demensia, diperkirakan mempunyai prevalensi $15 \%$ pada penduduk usia lebih dari 65 tahun (Fields RB, 1999).

Salah satu tahapan penurunan fungsi kognitif adalah Mild Cognitive Impairment yang merupakan gejala perantara antara gangguan memori atau kognitif terkait usia (Age Associated Memori Impairment/AAMI) dan demensia. Penelitian menunjukkan bahwa lebih dari separuh (50-80\%) orang yang mengalami MCI akan menderita demensia dalam waktu 5-7 tahun mendatang (Purwadi T, 2002).Pada tahun 2020 di negara maju orang berusia di atas 80 tahun akan meningkat sebesar 65\% dan mencapai 138\% di negara berkembang. Pada keadaan tersebut insiden seseorang menjadi pikun atau demensia adalah $1 \%$ pada usia 75 tahun dan meningkat menjadi $10 \%$ pada usia di atas 85 tahun. Sementara populasi saat ini menunjukkan 5-7\% 12 dari penduduk di atas 65 tahun menderita kepikunan atau demensia. Di Indonesia jumlah lansia di tahun 2000 
mencapai 15,3 juta $(7,4 \%)$ dan pada tahun $2005-2010$ diperkirakanmeningkat menjadi 19 juta (8,5\%) (Lumbantobing, 1995). Dari seluruh pasien yang menderita demensia, 50 hingga 60 persen diantaranya menderita jenis demensia yang paling sering dijumpai, yaitu demensia tipe Alzheimer (Alzheimer's disease) (Sadock, 2007).

Atas dasar permasalahan tersebut maka diperlukan penelitian yang mengkaji adakah hubungan hipertensi dengan gangguan fungsi kognitif pada lansia. Diharapkan nantinya dari hasil penelitian ini dapat digunakan sebagai masukan dalam upaya pencegahan dan penanganan gangguan fungsi kognitif

\section{METODE}

Rancangan penelitian yang dipergunakan dalam penelitian ini adalah observasional analitik dengan pendekatan cross sectional dilakukan di Posyandu Lansia Sumbersari Malang

Populasi penelitian ini adalah semua lansia di Kelurahan Sumbersari Malang, sampel penelitian ini diambil secara Cluster Sampling dari semua lansia hipertensi dan non hipertensi umur 60 -74 tahun di Posyandu Lansia Sumbersari RW 03 Malang yang memenuhi kriteria inklusi dan tidak termasuk kriteria eksklusi.

Kriteria inklusi semua anggota posyandu lansia yang hipertensi dan non hipertensi umur 60 - 74 tahun di Posyandu Lansia Sumbersari Malang, Penderita hipertensi $>5$ tahun, Pendidikan minimal tamat SD B, sedia menjadi subyek penelitian. Kriteria eksklusi penderita gangguan psikiatri, penderita diabetes mellitus, penderita penyakit jantung, penderita dengan riwayat stroke, penderita buta aksara, penderita gangguan pendengaran dan komunikasi Variabel bebas hipertensi. Variabel tergantung penurunan fungsi kognitif. Variabel perancu diabetes mellitus, penderita dengan riwayat stroke, penderita gangguan psikiatri.

Besar sample (n) pada penelitian ini dihitung dengan formula Slovin (1960): $\mathrm{n}=\mathrm{N} /\left(1+\mathrm{N} \mathrm{e}^{2}\right), \mathrm{n}=69 /$ $(1+6.5 \% .5 \%), \mathrm{n}=58,84, \mathrm{n}=59$ dengan $\mathrm{n}=$ besar sample, $\mathrm{N}=$ ukuran populasi, e $=$ nilai kritis (batas ketelitian) yang diinginkan

Instrumen yang digunakan dalam penelitian ini adalah pemeriksaan fisik yakni dengan tensimeter untuk mengetahui apakah sampel menderita hipertensi atau tidak, Lembar test Kuesioner MMSE (Mini Mental State Examination) dengan nilai antara 0-30 untuk mengetahui apakah sampel menderita gangguan fungsi kognitif atau tidak, stick tes untuk mengukur kadar gula darah sewaktu apakah sampel memiliki kadar gula darah yang tinggi atau tidak

Data penelitian diperoleh dari data primer pada penderita hipertensi di Posyandu lansia Sumbersari Malang yang dari hasil pemeriksaan fisik dan wawancara didapatkan keluhan tersebut.

\section{HASIL DAN PEMBAHASAN}

Penelitian untuk mengetahui hubungan antara hipertensi dengan terjadinya penurunan fungsi kognitif pada lansia. Pengambilan data dalam penelitian ini dilakukan dengan menggunakan lembar tes MMSE pada 63 sampel lansia yang memenuhi kriteria inklusi dan eksklusi di Kelurahan Sumbersari Malang. Hasil penelitian dilakukan uji hipotesis untuk melihat apakah ada hubungan hipertensi dengan penurunan fungsi kognitif pada lansia. Selanjutnya data yang diperoleh ditabulasi, kemudian disajikan dalam bentuk frekuensi distribusi, dianalisa dengan menggunakan Uji Chi-Square. didapatkan bahwa sampel yang mengalami penurunan fungsi kognitif sebesar 48 sampel (76\%) dengan jenis kelamin perempuan lebihb banyak yaitu 34 sampel (54\%), sedangkan sisanya yaitu 14 sampel (22\%) berjeniskelamin laki-laki. didapatkan bahwa sampel usia 6069 tahun berjumlah 39 sampel (62\%), 26 sampel (42\%) diantaranya mengalami penurunan fungsi kognitif, sedangkan sampel usia 70-74 tahun yang berjumlah 24 (38\%) keseluruhannya menunjukkan penurunan fungsi kognitif yaitu sebesar 24 (38\%). Berdasarkan tabel 5.3 didapatkan kecenderungan semakin tinggi stadium hipertensi semakin banyak yang mengalami penurunan fungsi kognitif yaitu sebanyak $50(79 \%)$ sampel diantaranya 3(5\%) sampel normal, $10(16 \%)$ sampel berada pada tingkatan prehipertensi, 13(20\%) sampel hipertensi stadium I dan sisanya 24 sampel (38\%) hipertensi stadium II. Pada penelitian ini dikatakan normal jika tekanan darah sistolik < $140 \mathrm{mmHg}$ dan diastolik $<90 \mathrm{mmHg}$, dan dikatakan hipertensi jika tekanan darah sistolik $>140$ dan sistolik $>$ 90. Berdasarkan tabel 2x2 diatas didapatkan nilai P 0,015 yang berarti terdapat Hubungan antara hipertensi dengan penurunan fungsi kognitif.

Pada penelitian ini dengan uji Chi Square terbukti ada hubungan antara hipertensi dengan penurunan fungsi kognitif dimana hasilnya dari uji analis menunjukkan bahwa nilai expected count $<5$ sebanyak 1 , dan juga dapat dilihat bahwa nilai signifikansi sebesar 0,015 di mana lebih kecil daripada $\alpha=0,05$ sehingga $\mathrm{H} 1$ diterima yang berarti bahwa terdapat hubungan yang signifikan antara hipertensi dengan terjadinya penurunan fungsi kognitif.

\section{SIMPULAN}

Berdasarkan hasil penelitian yang telah dilakukan, maka dapat ditarik kesimpulan terdapat hubungan antara hipertensi dengan terjadinya penurunan fungsi kognitif pada lansia di Posyandu Lansia Kelurahan Sumbersari Malang (p: 0,015),Didapatkan sampel mengalami penurunan fungsi kognitif pada laki-laki sebanyak $22 \%$ dan pada wanita sebanyak $54 \%$, didapatkan sampel mengalami penurunan fungsi kognitif pada umur 60-69 tahun sebanyak 42\% dan umur 70-74 tahun sebanyak 38\%,didapatkan sampel mengalami penurunan fungsi kognitif pada penderita, penderita yang tidak hipertensi sebanyak $5 \%$, prehipertensi 16\%, hipertensi, stage I sebanyak $20 \%$ dan Hipertensi stage II sebanyak $38 \%$.

\section{DAFTAR PUSTAKA}

Asosiasi Alzheimer Indonesia. 2003, Pengenalan dan Penatalaksanaan Demensia Alzheimer dan Demensia Lainnya. Jakarta, 75-80

Bird P Thomas, 1998 , Memory Loss and Dementia. In Harissons's. Principles of Internal Medicene. 14th Ed, McGraw-Hill, New York; 142 -149. 
Braunberger. 2001, The Clock Drawing Test. Available from http://www. neurosurvival. ca/ ClinicalAssistant/scales/clock_drawing_test.htm

Carlson N. 2004. Physiology of behavior. 8th ed. Pearson Education, Inc. United States of America ; 66-100.

Chen SH et al, 2006. Dose temporal pattern of esterogen exposure determines neuroprotective outcome in hippocampal neurons : therapeutic implications endrocinol; 147:5303-13. Diambil dari jurnal Khosama Herlyani et al, 2008

Crum RM., Anthony JC., Basset SS., Folstein MF. 2006. Population-Based Norms for the Mini-Mental State Examination by Age and Educational Level. The Journal Of The American Medical Association. http:// jama.ama-assn.org/content/269/18/2386. full.pdf + html

Djokomoeljanto R, 2005. Renin Angiotensin System and Aterosclerosis in : Tanuwidjojo S, Sungkar M.A, Rifki S (ed). New Trens in Cardiovascular Pharmacotherapy. Semarang : Badan Penerbit UNDIP : 122-32

Duss, Peter. 1996. Diagnosis Topik Neurologi, Anatomi, Fisiologi, Tanda, dan Gejala. Jakarta: EGC. 1-30

Erkinjutti T, Gauthier S. 2002. Vascular Cognitve Impairment. London : Martin Dunitz, Ltd; 9-20;27-37;67-177

Fields RB, 1999, The dementias in Clinical Neuropsychology, American Psychological Association, Washington DC.

Haller H, 1997, Endothelial function, General consideration, Drugs, pg 30.

Halliwell B, Gutteridge, 1999. Free radical in Biology and Medicine. New York ; Oxford University

Hartono B, 2002, Konsep dan Pendekatan Kognitif Pada Usia lanjut: Terfokus Pada Deteksi Dini. In : Cognitif Problem in Elderly, Temu Regional Neurologi Jateng DIY ke XIX.

Hartono B, Wibowo S, Rahmawati D, 2002. Cognitive problem in elderly. Procedding of Temu Regional Neurologi. Semarang : Badan Penerbit Universitas Diponegoro

Juby A, Tench S, Baker V. 2002. The Value of Clock Drawing in Identifying Executive Cognitive Dysfunction in People with a normal Mini Mental State Examination Score. CMAJ;167 : 859-8Jose C. Millan-Callenti, Javier T, Salvador PF, Isabel GA,Trinidad Lorenzo,ana M.2009. Prevalence of Cognitive Impairment: Effects of Level of Education, Age, Sex, and Associated Factors.Spain. Journal:http://www.ageing.ox.ac.uk/system/files/ cog.pdf

Kaplan H, Saddock B, Grebb J, 2010, Sinopsis Psikiatri Ilmu pengetahuan Perilaku psikiatri klinis, Bina Rupa Aksara, Tangerang. Kasper, D. L., Fauci, A. S., Longo, D. L., Braunwald, E., Hauser, S. L., Jameson, J. L. 2005.

Harrison's Principles of Internal Medicine. 16th edition. USA: McGraw-Hill. 2372- 2376.

Khosama Herlyani et al, 2008. Hubungan Kadar Serum Esterogen dengan Memory Performance pada wanita Pasca Menopouse, Neurona $25: 3$.

Kurlowicz L Wallace M. 1999. The Mini Mental State Examination (MMSE) Try this from The Hartford Institute for Geriatric Nursing New York University. Diunduh dari : www.HartFordign.org
Kurniati, Ari. 2011, Hubungan Antara Retinopati Diabetika dengan Gangguan Kognitif pada Penderita Pasca Stroke Iskemik. Masters thesis, Diponegoro University.

Kusumoputro S, 1999. Gangguan Fungsi Luhur Pada Cedera Kraniocerebral, Neurona.

Linsday W Kenneth et al, 1997. Neurology and Neurosurgery Ilustrated. 3rd Ed. Churchill Livingstone, New York, ; $105-120$

Lamsudin R. 1999. Demensia Vaskuler. Berkala Neuro Sains $1: 1-10$

Lawrence WKS, Caplan LR, Jong KS. 2008. Stroke Mechanism. In : Intracanial Atheroscheloris. Singapore: Blackwell Publishing Ltd : 57

Lezak MD, 1995, Neuropsychological assessment 3rd ed, New York:Oxford University.

Lumbantobing, S. M. 1995 . Demensia, Symposium Geriatric Uddate. Sabtu 5 November, Jakarta.

Lumbantobing SM. 1997. Kecerdasan pada usia lanjut dan demensia. Jakarta; BP FKUI; 1- 43.

Markam S, Markam SS. 2001. Pengantar neuro - psikologi. Jakarta: Balai Penerbit Fakultas Kedokteran Universitas Indonesia

Markum MS, 2002, Hipertensi, dislipidemia dan atherosclerosis, Dalam Simposium. Management of Hypertension in special conditions, Jakarta

Maslim R. 2001. Buku saku Diagnosis Gangguan Jiwa rujukan ringkas dari PPDGJ III,Jakarta; PT Nuh Jaya.

Martini FH, Judi LN, 2010, Anatomy and Physiology. 2thed, Inc.Benjamin Cumming, United States of America ; 88

Maxwell WL, 1999, Cellular responses to Ischaemic CNS Injury . In CNS Injury, Cellular Responses and Pharmacological Strategis, CRP Press LLC.

Netter H Frank. 1986, The CIBA Collection of Medical Illustrations. Vol I Nervous System : 147.

Purba JS. 2002. Demensia dan Penyakit Alzheimer.Jakarta: BP FKUI : 1-20

Purwadi T, 2002, Manajemen Penderita Mild Cognitif Impairment (MCL). Simposium Demensia, Pertemuan Ilmiah Nasional Neurogeriatri Pertama, Jakarta.

Reisberg B, Franssen E, Sekab SG, et al, 1989, Stage Spesific Incidence of Potentially Remediable Behavioral Symtoms in Aging and Alsheimer Disease : a study of 120 patiens using the BEHAVE - AD, Buletin of Clinical Neurosciences.

Reitz C, Tang MX, Manly J, Mayeux R, Luchsinger JA, 2007. Hypertension and the Risk of Mild Cognitive Impairment. Arch Neurol; 64(12):1734-1740

Ridker PM, Buring JE, Cook NR, Rifai N. 2003. Creactive Protein the Metabolic Syndrome, and Risk of Incident Cardiovascular Event : an 8-year follow-up of 719 initially bealthy American Women. Circulation, 107: 391-397

Rochmah W, Harimurti K, 2006, Demensia, In: Aru, Sudoyo, Setiyohadi B, Buku Ajar Ilmu Penyakit Dalam, 4th edn, Pusat Penerbitan Departemen Ilmu Penyakit Dalam Fakultas Kedokteran Universitas Indonesia, Jakarta.

Ropper, A. H., Brown, R. H. 2005. Adam and Victor's Principles of Neurology. 8th edition. USA: McGraw-Hill. 660-664 
Rovner BW, Folstein MF. 1987. Mini-mental state exam in clinical practice. Hosp Pract:;22(1A):99, 103, 106, 110.

Ruchinkas RA, Singer HK, Repetz NK. 2001. Clock Drawing, Clock Copying and physical abilities in geriatric rehabilitation. Arch Phys Med Rehabil 82 : 920-24

Sadock, Benjamin James; Sadock, Virginia Alcott. 2007. Delirium, dementia, amnestic and cognitive disorders. Kaplan \& Sadock's Synopsis of Psychiatry: Behavioral Sciences/Clinical Psychiatry, 10th Edition . Lippincott Williams \& Wilkins.

Setiati, Siti. 2006. Proses Menua dan Implikasi Klinisnya, dalam:Buku Ajar Ilmu Penyakit Dalam Jilid III Ed. IV. Jakarta: FKUI

Shiang Wu-Ming,Tsuo-Hung Lan, Chun-Min Chen, et al, 2011, Socio-demographic and health-related factors associated with cognitive impairment in the elderly in Taiwan, BMC Public Health. 2011; 11: 22. Published online 2011 January 11. doi: 10.1186/1471-2458-11-22 http:// www.ncbi.nlm.nih.gov/pmc/articles/PMC3027136

Sjahrir, H. 1999. Pengenalan Demensia, dalam Sjahrir, H, Nasution, D, dan Rambe, H. (Eds) Demensia, hal 5999. USU - Press. Medan

Sloane, Ethel. 2003. Anatomi dan Fisiologi Untuk Pemula (Anatomy and Physiology An Easy Learner). Jakarta: EGC

Soewoto, Hafiz. 2002. Peran Radikal Bebas Pada Proses Menua. Pertemuan Nasional Neurogeriatri Pertama, PERDOSSI, Jakarta: FKUI

Solso R L, Maclin O H, Maclin M K. 2008. Psikologi Kognitif Ed.8. Jakarta: Penerbit Erlangga

Strub, R. L., Black, W. 1993. Neurobehavioral disorders, A clinical approach. Philadelphia: F.A.Davis Company.

Suhr, JA, Gracc, J. 1999. Brief Cognitive Screening of Right Hemosfer Stroke : Relation to Functional outcome. Arch Phys Med Rehabil.

Swan GE, Carmelli D, Larue A. 1998. Systolic Blood pressure tracking over 25 To 30 years and cognitive performance in older adults.

Trimble, LA, Sunberg, S., Markham, L, Janicijevic, S, Beattie, BL, Meneilly, GS, 2005. Value of The Clock Drawing Test to Predict

Tzourio C, 2002, Vascular factor and cognition: toward prevention of dementia, Medicografia.

Wibisono Sasanto, Prof, dr, DR, SpKL, K. : "Kuliah Consultation Liaison Psychiatry”. FK UI, 2001

Wiyoto, 2002, Penurunan fungsi kognitif Pada Stroke in Pendidikan Kedokteran Berkelanjutan ilmu penyakit saraf, FK UNAIR, Surabaya.

Wong, Tak Pan. 2002. Aging Of The Cerebral Cortex Jurnal:http://www.med.mcgill.ca/mjm/v06n02/ page $\% 20104113 . P D F$

Yustiani D, 2002, Demensia, Diagnosa dan Penatalaksanaan, FK UNAIR, Surabaya.

Zhu L, Fragtioni L, Guo Z, Tores HA, Winblad B, Viitanen M. Association of Stroke with Dementia, Cognitive Impairment 